\title{
THE INFLUENCE OF ONLINE TEACHING ON FACE-TO-FACE TEACHING PRACTICES
}

Norma I. Scagnoli, Ph.D.

Lydia P. Buki, Ph.D.

Scott D. Johnson, Ph.D.

University of Illinois at Urbana Champaign

\begin{abstract}
The integration of online technologies in educational practice is rendering new opportunities for teaching and learning. It is known that instructors who have taught fully online courses have acquired new skills and have had the opportunity to implement novel pedagogical practices in the online environment. However, it is unclear whether direct exposure to fully online teaching facilitates the integration of technology in traditional classrooms. This qualitative investigation examined the transfer of four experienced faculty members' pedagogical practices from online to face-to-face teaching. Results of this case study show that (a) the instructors' online teaching experience influenced their perceptions and understanding of online pedagogical strategies, and (b) the transfer of pedagogical strategies back to the classroom is a complex process influenced by the instructors' teaching style, satisfaction with working in the online environment, and the similarity of content and context between online and face-to-face courses. These findings have the potential to inform innovations in faculty training and development and to promote further research in this area.
\end{abstract}

\section{KEYWORDS}

Pedagogy, Collaboration, Technology, Accountability, Online, Face-to-face

\section{INTRODUCTION}

A growing body of literature suggests that when instructors venture out of the traditional classroom to engage in online teaching, they acquire new skills and competences [1, 2, 3] and perform roles different than those performed in the classroom [4]. For example, faculty who teach online gain familiarity with uses of technology, online pedagogical practices, alternative forms of accountability, and novel applications of techniques for collaborative learning $[5,6,7,8,9]$. The fact that experience in Internetbased distance education seems to facilitate the integration of online technologies into the classroom has been raised as a secondary finding in several studies [5, 6, 8, 9, 10, 11, 12]. It is yet unclear, however, how the process of exposure to fully online teaching influences this integration. Suter concluded that "The teaching of online classes resulted in the faculty's greater use of technology-related learning activities in their on-site classes" [12, p. 234]; Fetzner indicated that faculty "change their teaching process and bring lessons learned in the online environment to campus-based classrooms” [6, p. 237]; and Guidera quoted a faculty member who said "I now use online tools extensively and routinely to enhance my regular classroom courses" [13, p. 111]. These findings, although limited in scope, suggest that to facilitate technology integration, faculty should be trained in distance education methods and technologies and should be encouraged to use those methods back in the classroom [2, 8, 9, 14].

Our study aimed to close the current gap in research by exploring, in depth, the influence of online teaching on face-to-face teaching practices. To reach a better understanding of what practices are brought 
back to the classroom by those who have been exposed to fully online teaching, we examined both the type of changes and the motivation behind those changes. Teaching practices and the transfer of pedagogical practices from the online to the face-to-face classroom were analyzed from the perspective of the instructor, the actual teaching materials, syllabi, course plans, and other course documents.

\section{RESEARCH DESIGN}

This study followed a qualitative research design and more specifically, a collective case study [15]. The overarching question that motivated this investigation was: "How does previous online teaching experience influence upcoming classroom teaching practice?” Additional questions that guided the data collection and analysis included: How do faculty describe their classroom teaching experience after teaching online? Are there changes in face-to-face instruction that can be attributed to the experience of previous online teaching? What pedagogical strategies do instructors transfer from online to face-to-face teaching? What benefits do they expect from that transfer?

\section{A. Participants}

Four faculty members with extensive previous teaching experience in graduate programs in higher education, both in face-to-face and online courses, participated in this study (see Table 1). Participants had to meet the following inclusion criteria: (a) at least 3 years of classroom teaching experience in higher education, (b) had taught at least one graduate distance education course via the Internet, (c) had taught at least one graduate face-to-face course equivalent in discipline and credits to the course taught online, (d) had taught at least one face-to-face course before and after having experienced at least one semester teaching online, and (e) had taught the online course as part of an established curriculum in a degree program.

It was important for faculty to have previous teaching experience because it is known that experienced instructors have a different way of incorporating changes into their teaching and, seasoned in their profession, they have achieved higher competence in problem solving than novice teachers [16, 17]. As Table 1 shows, all four faculty members were seasoned teachers with the majority having over 10 years of classroom teaching and at least 2 years of online teaching experience at the time of the study.

\begin{tabular}{lllll}
\hline Participant & $\begin{array}{l}\text { Teaching } \\
\text { Experience }\end{array}$ & $\begin{array}{l}\text { Online } \\
\text { Experience }\end{array}$ & Background & Department \\
\hline Prof. Allen & 14 years & 2 years & $\begin{array}{l}\text { Adult ed., organizational } \\
\text { development }\end{array}$ & Human Development \\
\hline Prof. Bilbao & 33 years & 8 years & Adult ed., Psychology & Teaching \& Learning \\
\hline Prof. Chang & 14 years & 6 years & $\begin{array}{l}\text { Training and } \\
\text { organizational development }\end{array}$ & Human Development \\
\hline Prof. Davis & 40 years & 6 years & $\begin{array}{l}\text { Psychology of teaching and } \\
\text { learning }\end{array}$ & Teaching \& Learning \\
\hline Average & 25.25 years & 5.5 years & & \\
\hline
\end{tabular}

Table 1: Participants’ Background Information

The identity of the faculty members and identifying information are altered in this article to protect the confidentiality of the participants. For example, all participants are presented as male participants. Although this masks the gender diversity in the present example, it was important to characterize everyone as being of the same gender to protect confidentiality given the small sample size. 
The courses taught by the participants at the time of the study were all within the social sciences (see Table 2). As shown in Table 2, two of the participants were teaching the same course online and face-toface and the other two were teaching two different courses in these modalities.

\begin{tabular}{cll}
\hline Participant & Online course & Face-to-face course \\
\hline Prof. Allen & Advanced graduate course (Summer) & $\begin{array}{l}\text { Foundation course in Human } \\
\text { Development (Fall) } \\
\text { Pasic theory of Teaching \& Learning } \\
\text { (Summer) }\end{array}$ \\
Prof. Chang & Theories of Education (Spring) & $\begin{array}{l}\text { Advanced course in Human } \\
\text { Development (Summer) }\end{array}$ \\
Prof. Davis & $\begin{array}{l}\text { Foundations of Teaching \& Learning } \\
\text { (Spring) }\end{array}$ & $\begin{array}{l}\text { Development (Fall) } \\
\text { Foundations of Teaching \& Learning } \\
\text { (Summer) }\end{array}$ \\
\hline
\end{tabular}

Table 2: Participants’ Types of Course Assigned

\section{B. Method}

To enhance credibility, this case study included multiple sources of information as well as multiple methods of data collection [18, 19, 20]. Specifically, three methods of data collection were used in six data-collection stages (see Figure 1) which included interviews, observations, and study of documents. The process of data collection took five months to complete and it was conducted by one researcher.

\begin{tabular}{|c|c|c|c|c|c|c|c|c|}
\hline 点 & $\begin{array}{l}1 \\
\rightarrow\end{array}$ & $\begin{array}{l}2 \\
\rightarrow\end{array}$ & $\begin{array}{l}3 \\
\rightarrow\end{array}$ & $\begin{array}{l}4 \\
\rightarrow\end{array}$ & & $\begin{array}{l}5 \\
\rightarrow\end{array}$ & & 6 \\
\hline 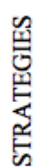 & Focus Interview & $\begin{array}{l}\text { Preliminary Study } \\
\text { of Documents }\end{array}$ & $\begin{array}{l}\text { Open -Ended } \\
\text { Interview }\end{array}$ & $\begin{array}{c}\text { In-depth } \\
\text { Study of } \\
\text { Documents }\end{array}$ & 造 & Observation & 造 & $\begin{array}{l}\text { Follow-up } \\
\text { Interview }\end{array}$ \\
\hline
\end{tabular}

Figure 1. Steps in Data Collection

Focus interview. First, the primary author met individually with each faculty member to learn about the faculty member's teaching philosophy. This in-person interview took 40 to 60 minutes and was conducted following an interview guide.

Preliminary study of documents: The researcher examined the course syllabi and other documents (i.e., class schedules, teaching statements, or semester activities plan) with the purpose of gaining an improved understanding of the organization and content of the courses taught by each instructor. The information examined included course description, expectations for the course, the type of instructional strategies proposed, any possible evidence of use of online strategies, details of the technologies used in the class, as well as other information that could help the researcher better understand the courses that were being explored.

Open-ended interviews: The primary author met with the faculty members for a second time with the purpose of inquiring about the faculty members' perception of the influence of online teaching on their classroom teaching. This interview took about 90 minutes and it followed an interview guide that included questions about pedagogical practices and skills acquired in online teaching. The questions in 
the interview guide were drawn from the principal investigator's experience and from the research study by Schoenfeld-Tacher and Persichitte [21], which provided information about the knowledge and abilities that instructors possess or acquire when teaching online.

In-depth study of documents: An exhaustive review of the course documents (i.e., course syllabi, assignments, assessments, instructional design) was conducted with the aim of examining the pedagogical and teaching style of each participant in both online and face-to-face courses. Two sets of documents were analyzed for each case. One set was from the online course previously taught by the participant, and the other was from the face-to-face course taught subsequently, that is after teaching the online course. For example, one of the online courses studied was taught in the Fall semester and the face-to-face course was taught the following summer. In this way, the researcher could determine if there was any influence of online teaching in the face-to-face teaching. The instrument used by the researchers to gather information in this study of documents was organized by phases of instruction [22], namely (a) presenting information, (b) guiding the learning process, (c) practicing or applying new concepts or skills, and (d) assessing learning.

Direct observation: This stage consisted of direct observation of face-to-face classes. An average of three face-to-face classes was observed for each case. It took two months to complete the direct observation stage for each case. The observations focused on identifying the types of activities performed by the instructor and on uncovering possible evidence of integration of Internet applications in face-to-face teaching. For example, evidence could include the use of the Internet in the instructors' communications with students, in students' interactions with each other (such as use of online discussion forums in the face-to-face class), or in students' preparation of assignments (such as the use of the internet for research or group activities, or the use of weblogs for writing assignments instead of printed papers).

Follow-up interviews: The primary author sent each study participant a summary of the data collected for member checking. A week later the primary author met individually with each participant to conduct the last interview of the study. In this interview, the researcher presented the instructors with statements derived from the data collected throughout the study, and elicited reflections and comments that were subsequently integrated into the final version of the results.

\section{Data Analysis}

Data analysis began soon after the first step of data collection. This practice, known as interim analysis, facilitated the emergent design and the emergent structure of later data collection phases [23]. Each case was analyzed individually (i.e., within-case analysis) and was later compared and contrasted with the other cases (i.e., cross-case analysis). Within-case analysis involved a close scrutiny of each case, enabling the researcher to gain in-depth knowledge of each. The cross-case analysis facilitated a more holistic understanding of the phenomenon and contributed to building a general explanation that would fit all cases [24] while maintaining each case's identity and uniqueness. The cross-case study was not meant to generalize findings, but to provide a way to reach a more clear understanding and explanation of the phenomenon [19, 24].

\section{RESULTS}

\section{A. Within-Case Analysis}

This section presents the main features of each case, including descriptions of the instructors' teaching experience as well as the instructors' self-perceptions of the influence of their online teaching practices on 
their classroom practices.

\section{Case One: "Face-to-face Class in the Face-to-face Arena"}

Professor Allen's teaching philosophy was marked by his interest to blend theory, research and practice to help students better understand the importance of the foundations in the field. His teaching style was that of a formal authority with a clear plan to cover content. At the same time, he guided students' interactions and developed participatory activities to keep them engaged in the topics presented that day. His classes were well organized, engaging, and centered around the instructor's guide and expertise.

After several years of rewarding experiences teaching in the traditional classroom, Professor Allen accepted the invitation to teach for an online program. He strongly believed that to replicate the success he enjoyed in the face-to-face experience, he needed to reproduce his face-to-face class as closely as possible in the online environment. Without prior online experience, for his first online course he moved an existing face-to-face course to the online environment, replicating pedagogical practices as much as he could. After the first semester teaching this course, he decided to make some changes to the online course given that he had a more clear understanding of the capabilities of the new online environment. The following semester he went back to classroom teaching without leaving his online course, and has continued teaching in the two formats ever since.

Two years after having started teaching online, Professor Allen's experience in the use of communication and information technologies was not quite evident in his face-to-face teaching. "I haven't gone from online to the face-to-face [teaching]; I have gone the other way around," he said. He perceived it was logical to move his current practices to the online environment but he did not see any advantages of bringing online practices to the face-to-face class. Professor Allen made a clear distinction between the pedagogical practices used in his online and his face-to-face courses. He said "I try to make my face-toface class in the face-to-face arena," implying that he did not like to mix online and face-to-face activities in his classes. With one exception, his face-to-face teaching had no traces of the online teaching experience. Everything that happened in his face-to-face class was done, presented, or discussed in the classroom as it was before he taught online. Also, the uses he made of web technologies in his face-toface course were the same as those he had relied on before teaching online: using the library's electronic reserves, using links to articles in electronic journals, and email for communication. The one exception was that he started to use his students' comments in the online course discussions to trigger interaction in the face-to-face classroom. He selected ideas, paragraphs, or chunks of comments from the interaction in the online class and adjusted them to be incorporated into sections of the presentation or activities in his face-to-face class. This transfer was clearly facilitated by the similarity of content covered in both courses. He said that this was a good strategy because it turned out to be a good catalyst for discussion in the face-to-face class.

He did not identify any other strategies or practices that he wanted to transfer to the face-to-face class. He perceived that the transfer of online technologies presented several constraints, such as the time required for implementation, the risk of student complaints, the lack of faculty incentives for the time devoted to integrating technology into face-to-face teaching, issues of intellectual property, and finally, no payoff in terms of enhancing the students' learning experience. For example, he believed that incorporating discussion forums in the face-to-face class would take extra time for students and would not add to their learning experience. He remembered one student in particular who said: "please, please, do not make us go online to work, don't add questions before class, don't add extra layers to our class assignment” and added that students do not need to use technology to engage in meaningful learning experiences. 
In addition, Professor Allen said that uploading materials to the web was "quite a time intensive endeavor," and perceived that if he wanted to incorporate the use of new communication tools in his faceto-face class, it would take as long as it took when he was creating his online class. He did not see any reason to use his time doing that for a class that already interacted very well face-to-face. He added:

...one of the challenges is that if you place an $\mathrm{X}$ amount of time in teaching and technology at the expense of research, you jeopardize your career because the rewards aren't here for teaching; [they] are really for research and grant writing, so it is a delicate balance.

He also indicated concerns about intellectual property and copyright, which made him rethink the need to make class materials available online: "I don’t put all my materials up in [Course Management System; CMS] for my face-to-face course because you upload things in a site like that, and students can access and take," he remarked. He added that he had once experienced a case of violation of copyright. He also indicated that he did not ask students to find class materials on their own on the web, because he has observed careless use of the web resources by students. He emphasized that students had to refer to scholarly publications found in the library or the web links recommended in the class. Encouraging the search for online resources could be an invitation to plagiarism or "an easy way out." He explained:

I don't ask students to “Google” something on the Internet, because that is kind of the easy way out. I want them to go to the library and search in journals, also in online journals . . . sometimes students see Google as an invitation to do research in an easy way . . . and frequently the Google site or the Internet becomes the gospel.

\section{Case Two: “ Online Teaching has Changed Very Little [my] Face-to-face Teaching”}

“Online [teaching] has changed very little my face-to-face [teaching]. You will see. Very little," said Professor Bilbao when we started talking about the influence that online teaching might have had on his face-to-face teaching. Professor Bilbao's teaching philosophy focused on the development of students' skills in critical thinking and collaborative learning, and he made it a priority to help students experience and develop an appreciation for learning communities. His teaching style was a combination of formal authority and facilitator. He preferred to closely guide students' learning experiences but at the same time he generated opportunities for them to learn on their own. Professor Bilbao had conducted research in the area of educational technologies some time before he was invited to design and teach his first fully online course. He reported that it was his previous exposure to information technologies (IT) that influenced his use of technology in his face-to-face course, and not his later exposure to online teaching. He admitted that his interest in community building had been very well supported by the use of IT, complementing the face-to-face interaction with email communication. IT had enabled him to reach individual students in a crowded face-to-face course, something he would never have achieved had his interaction with students been limited to the face-to-face arena in his large course with 250 students. Similar to Professor Allen's experience, Professor Bilbao started his online teaching by redesigning a face-to-face course to be taught in the online environment. His main objective was to replicate online the face-to-face class activities, especially the group and collaborative activities. Despite his previous experience in the use of technologies, he admitted that moving his course to the online environment was not a good experience from the very beginning. This first online course took longer to prepare than he had expected and demanded much more effort to teach than the face-to-face course. Moreover, he perceived that the activities did not have the same outcomes as when they were done face-to-face: "We could not keep up with all the activities we had designed. We could not give enough feedback because we could not keep up." After his first semester of online teaching, he revisited his practice and worked to redesign the online course to better reflect what he values: a collaborative and interactive learning experience. His first experience helped him realize that transferring pedagogical practices from one environment to the other was not a direct move, especially when the type of students in the online course was different from his face-to-face course. He indicated that to think about transferring back from the online environment to the 
face-to-face course was something that had to be carefully studied before implemented:

The online community that I am dealing with, they are self-directed learners; they are bringing an awareness that they have to be participants in the online learning. . . the undergrads [in the faceto-face course] are not self-directed learners, besides we are competing with other courses in their major...

Professor Bilbao voiced two main concerns about bringing online practices to the face-to-face course. One concern was related to the time that online interaction demanded: "we tried to use an online system [in the face-to-face course], but students were too busy with the other classes to come along," also, "how do you [instructor and TAs] keep up with all their answers?" and "how do you give good feedback to all?" He also feared that integrating online pedagogical strategies in his face-to-face course might hinder students' participation: "That is my nervousness about doing that, I am not sure that students will participate as openly.”

In his eight years of online teaching, Professor Bilbao has transferred to the face-to-face class a few strategies from the online course with the purpose of enhancing students' engagement. Two of the strategies that he brought from online teaching to the classroom were the inclusion of students' comments sent to him by email about the topics in his weekly lectures, and the practice of publishing his lecture (with the students' comments) on the course website. This transfer was encouraged by students' satisfaction, since they found it very motivating to have the opportunity to participate in the class lectures, and later see the lecture and contributions published in the course website. Still, the strategies he transferred from the online course were minimal, and Professor Bilbao explained that he did not want to overwhelm students with class assignments or to limit his availability to engage in other meaningful learning interactions. He explained that his face-to-face course included enough activities to fully engage students in classroom interaction, and that adding online elements such as a forum would not add to the learning experience, but very likely could turn into an overload for both students and instructors. He added: "I don't have time to read all messages in the online class, so how do I do it if I have one [online forum] in my face-to-face class?” Another concern he had was related to the increased need for assistants to provide teaching support and supervision.

\section{Case Three: “Multiple Alternatives to Engage Students' Learning”}

Professor Chang's teaching philosophy was geared towards encouraging discovery and exploration, and providing opportunities that would match the students' interests and previous experiences. He believed that his role as instructor was to provide information through his lectures and feedback, and that students' learning also involved exploring and finding other sources that would help them understand better. His teaching style was that of a facilitator and demonstrator aiming to develop mastery and thinking skills in his students. Professor Chang taught the same courses in the Department of Human Development to two different groups of students, one online and the other face-to-face. His face-to-face classes showed the influence of his online teaching in several practices: (a) he had created an online discussion forum for face-to-face students' interaction outside of class; (b) students' contributions to the forum were part of the face-to-face class discussion; (c) the face-to-face course used a CMS that hosted all class materials and student assignments; and (d) the instructor used different online and printed sources of information for each topic and included materials that he had developed for the online course. The latter was one of the most important manifestations of the influence of online teaching in the classroom. The instructor said that in his online teaching he had learned that, besides the face-to-face contact, there were "multiple alternatives to engage the students' learning," and he had realized that he could enrich his face-to-face class by bringing the same variety of formats that he used in his online classes. These formats were presentation slides, audio files, text that was the script of his audio comments, and video files. This variety of materials was incorporated to the face-to-face course as an additional resource to complement 
the classroom lectures.

About his approach to face-to-face teaching after his online experience, he said that he did not perceive a big difference between teaching online or face-to-face. "I feel equally responsible for structuring the process. . . . that is my overall responsibility. . . . I don't think that that is different.” He added that his online teaching experience had taught him that organization and clarity in teaching made learning easier.

Professor Chang had both adopted and adapted activities from his online course to be used in his face-toface course. For example, he incorporated the use of an online discussion forum for collaborative work, through which students could see and review each other's writing assignments. Such practice expanded the audience of students' work from the instructor only to peers as well. Professor Chang emphatically said:

What I really, really like about the online environment is the ability for people to look at other people's work. It does a couple of different things: (a) for competitive people, [it] creates an opportunity to see where you fit with your peers; it tells you if you are competitive or not; (b) it extends the amount of things that you can learn, such as how others communicate ... ; (c) it lets you learn your stuff and what others have been learning, too; [and] (d) it also teaches how others organize information. That is core in the course I teach, [so it] is like modeling what is expected, and what it does ... . I don't have to make it explicit; it becomes very obvious I don't have to reinforce it. That is something that I could not do in a standard face-to-face classroom without the electronic support.

In sum, Professor Chang reported that the online environment hosted elements that clearly supported his teaching philosophy, such as fostering a community of learners, encouraging discovery and exploration, and providing opportunities for sharing interests and experience. He also reflected on the fact that transferring the use of a CMS to the face-to-face course helped with class organization and management.

\section{Case Four: "A class Where there is Discussion Going On”}

Professor Davis said that he first approached online teaching as an "elaborated correspondence course that used more sophisticated methods" for delivery of materials. But soon, he said, he realized that the use of the Internet did more than just facilitating the delivery of materials. Given that the Internet allowed for powerful interaction in the online environment, his online teaching moved from an independent-studytype experience to a more integrated and collaborative environment. His teaching philosophy has always focused on encouraging learning by exploration and individual discovery. His role in distance education now was that of facilitating the interaction within the student cohorts and the sharing of projects, which created as an opportunity for building "community knowledge." He also started exploring learning as a social construction of knowledge. As a result of this combination of inquiry and social constructivism, he believes that his role is to give encouragement to learners "to wonder about things . . . and students have the responsibility and my permission to do that.”

There were three aspects of his face-to-face teaching that clearly demonstrated the influence of his online teaching experience: the use of online collaboration tools such as wikis and discussion boards, the implementation of a variety of peer-to-peer and group online activities for off-class interaction, and the setting of new rules for class attendance, which required students to attend not every day but only the last three sessions of the course. This last aspect was unusual for an on-campus course and, surprisingly, the class had a very high rate of student attendance. 
Professor Davis said that the learning outcomes in his online course encouraged him to incorporate activities from the online class into his classroom teaching. "In the online course, I put most of my effort in the [course] organization; I give students a lot of latitude/opportunities to follow assignments," and the students' production was superior, "[because] most of them did a better job than the students in face-toface." Therefore, he changed the face-to-face course structure and requirements to facilitate the integration with the online environment. The pedagogical strategies that Professor Davis used in his faceto-face teaching were a combination of traditional and online pedagogical strategies. For example, student-to-student interaction via the online forums was an important part of the face-to-face course:

In the way that I created the forums, and the forum 0 [zero, for students-only communication], there is all the openness in the world to say something . . . students have things to say and don't have anybody to talk to... their little daily achievements in the classroom and their little failures . . . they really don't have many people to talk to... their spouses don't want to hear about it . . . and they don't have time to talk to colleagues in school about it. I think that these students need [a channel to communicate], and I am responsive to the needs, and they talk to each other in the forum. . . then they come to class, and they hardly talk to each other, and you see the conversation that is going on online and think they will communicate to each other, but they don't. Once one student said in class, "Finally I have a class when there is some discussion going on" and he was talking about the online discussion.

The way that the instructor handled communication with students in the face-to-face course was also very similar to how he handled it in the online class. He discouraged individual email communication in his face-to-face course in favor of the use of the discussion forum.

The instructor had also transferred activities and assignments from his face-to-face teaching to his online teaching practice, and then he had brought them back to the classroom in a new format. For example, essay writing, which was an important part of the activities in his face-to-face courses, became collaborative writing projects in wikis for both the online and the face-to-face courses; multiple web resources (a few suggested by the instructor and a lot suggested by students) were the source to engage students in self-exploration and inquiry; and e-portfolios became a requirement for online and face-toface students. Of the four cases, this one was the only case that incorporated online assessment strategies in the face-to-face course. For example, the e-portfolio determined the course grade, and the evaluation and assessment of students' performance was based on the results of the (mostly online) activities completed. Both the online and face-to-face courses shared the same grading policy.

Motivation for Professor Davis to transfer online pedagogical strategies to his face-to-face class included both pedagogical and classroom management reasons. The implementation of the discussion forum for guidance and social interaction was motivated by an interest in enhancing learning and collaboration, as well as a way to improve the channels of communication among students and between the students and the instructor. The use of wikis as a tool for collaborative writing facilitated the "community construction of knowledge," a concept strongly supported by Professor Davis' teaching philosophy. Wikis also proved to enhance the quality of students' writing; he remarked that "writing for a wider audience makes students' work of a higher quality" compared to writing only for the instructor as their audience. The use of a CMS also provided flexibility and mobility of the course contents and interaction. Having the entire course available online substantially facilitated the learners' access to the course materials: "those that do not come to lecture have access to the lecture notes, slides, or readings," and they did not miss participating in the class interaction. 


\section{B. Cross-Case Analysis and Discussion}

The data were analyzed across all the cases to achieve a more holistic understanding of the transfer of online practices into classroom teaching. This comparison and contrast of cases provides a general explanation that suits all cases while maintaining each case's identity and uniqueness. The results of the cross case analysis is organized by each research question.

\section{a. How do faculty describe their classroom teaching experience after teaching online? Are there changes in face-to-face instruction that can be attributed to the experience of previous online teaching?}

Instructors' descriptions of their teaching experiences suggests that new pedagogical practices used in online teaching are more likely to be transferred back to the face-to-face courses when the courses share the same content. For example, Professors Chang and Davis taught the same courses online and face-toface, and in both cases the transfer of pedagogical strategies from their online practice back to the classroom was more evident than in the cases of Professors Allen and Bilbao, who taught different courses online and face-to-face. These results suggest that the efficiencies gained through the implementation of online activities in the same course that was taught in face-to-face format motivated a direct transfer from one format to the other. These findings are consistent with previous research suggesting that online teaching increases faculty members' readiness to integrate technology in the classroom [6,13], and that instructors come back to the classroom with a new repertoire of pedagogical strategies [12]. The findings also suggest that possessing knowledge of online education practices and theory, as well as having some expertise using online applications, are not enough to guarantee transfer to the face-to-face environment, which is consistent as well with previous research findings $[2,11,12]$. The faculty members' descriptions of their experiences suggests that several factors influenced their decision to transfer teaching strategies acquired online to the classroom: (a) their teaching styles or preferences, (b) their perception of online and campus education, (c) their proficiency in the management of online applications, and (d) their previous experiences transferring pedagogical strategies from their face-to-face to their online classes. With regards to teaching styles, instructors who took on the role of facilitators and left room for student-led activities were more likely to bring online applications back to the face-to-face classroom. In contrast, instructors who played the role of the expert or formal authority were less likely to transfer the strategies used in the online class to their classroom teaching. They preferred to participate in all interaction in the class, and perceived that online education should replicate the on-campus instructorcentered teaching context.

With regard to instructors' management of online applications, those who emphasized the need for technical and graduate student support seemed less confident transferring online strategies to the classroom setting. Finally, instructors who described having more problems or higher workload in their move from face-to-face to online teaching showed less interest in transferring new strategies back to the face-to-face class, fearful that the move would bring similar problems and work overload.

\section{b. What pedagogical strategies do instructors transfer from online to face-to-face teaching?}

This investigation presents evidence that the transfer of pedagogical strategies varies across phases of instruction: presentation, guidance, practice and assessment [22]. In the phase of presentation of new materials, the strategies most commonly used online and transferred to face-to-face teaching included: (a) the use of similar presentation materials, namely online presentations, web pages, links, audio and video files, and text documents; and (b) the inclusion of student-generated content in the lectures or presentations. 
In the phase of guidance or interaction, the most important transfer was the incorporation of online discussion forums and chat sessions in the face-to-face course as a way to respond to students' questions and for clarification of concepts.

In the practice phase, where students are expected to apply new knowledge or skills, there were three strategies that were transferred to classroom teaching: submission of assignments via online conference system or CMS, peer review of assignments, and collaborative writing or group work using online collaboration tools such as wikis.

Finally, the phase of assessment reflects the least transferred of online practices. Only one of the four participants, Professor Davis, had included in his face-to-face course an evaluation rubric that reflected assessment for the use of online strategies. Specifically, he assessed participation in the discussion forum and fulfillment of assignments in the online environment.

\section{c. What benefits do they expect from that transfer?}

There were multiple reasons that motivated the instructors to transfer pedagogical strategies from the online to the face-to-face course: (a) ability to improve learning outcomes, (b) ability to increase students' motivation, (c) interest in introducing new pedagogical practices, (d) ability to update class materials, (e) ability to engage students in different ways and appeal to different learning styles, (f) ability to facilitate access to class materials, (g) potential to improve communication, and (h) ability to re-organize and recycle teaching materials. In the following paragraphs, we provide a more detailed explanation of the motivations for transfer.

Better learning outcomes. Two factors motivated the transfer of pedagogical practices from the online course to the classroom: the results of comparisons of students' achievement between online and face-toface students (i.e., "many of them [online students] do a better job than the students in face-to-face...”), and the discovery of an online pedagogical technique that resulted in good learning outcomes. Evidence of this was found in several comments by Professors Chang and Davis: "seeing each others' work [via the online forum] is motivating and enlightening .... and they [almost] set the bar for the quality of the writings,...” (Professor Davis)

Increased students' motivation. Professors Chang and Davis agreed that the use of peer review and collaborative writing in online learning had enhanced students' motivation and quality of work, "changing the audience of the students' work from me [the instructor] to the rest of the class" (Professor Davis).

Interest in introducing new pedagogical practices. Transfer was also motivated by the instructors' interest in transferring pedagogical practices that could be easily implemented when used in the face-to-face class (i.e., peer review activities and collaborative writing via wikis).

Ability to easily update class materials. Having the online class in a CMS made it easy to upload and update class materials. Three of the instructors thought that this was a practice that their face-to-face course could benefit from, so they either adopted a CMS for the face-to-face course (such as Professors Chang and Davis did), or they adopted one of the activities. Professor Bilbao, for example, put his students in charge of using web search for updating resources and information about recent research on class-related topics. 
Ability to engage students in different ways. The online environment provided new ways for students to share their work or life experiences with the rest of the class. For example, Professor Davis indicated that when he saw students in the online class communicating and sharing information as colleagues, he decided that students would benefit if he provided that avenue in his face-to-face course. He then adopted the same online conferencing system that he used in the online course and subsequently observed similar engagement, collegiality, and sharing of experiences as in the face-to-face course.

Facilitated access to class materials. Three of the four participants reported that having the materials available via CMS or a web page enabled students' access to these materials, which could be an advantage for on campus students also. Consequently, they transferred this practice to the face-to-face class. Professor Davis reported "[I realized] those that were commuters could benefit with this system from [24/7 access] too.”

Improved channels of communication. The use of a discussion forum and/or a CMS in the face-to-face course was motivated by the fact that it helped faculty communicate with the students, keep track of messages sent, and organize communication in the course. Professor Chang reported that he found it easier to post announcements on the WebBoard ${ }^{\mathrm{TM}}$ to communicate with students in the class rather than using email for that purpose. In addition, the use of synchronous systems allowed faculty to host online office hours so that students could reach them or their TAs remotely, without having to come to campus.

Ability to keep class materials organized. “... I learned I can do things with technology, get things organized well in advance... I could not do that before ...," said Professor Chang explaining another reason why he transferred online practices to the face-to-face classroom.

\section{CONCLUSION}

In response to the overarching question that guided this study, How does previous online teaching experience influence upcoming classroom teaching practice?, the findings provide evidence that online teaching experience has an influence on some face-to-face teaching practices, although not all instructors who have taught fully online courses transfer online practices to the classroom, as suggested by previous studies [2, 11, 12]. Our findings suggest that certain factors are more influential to instructors' readiness to transfer pedagogical practices from online teaching to the classroom. For example, transfer is more likely to occur when the instructor has had a satisfactory previous experience in the online environment, and when there is close similarity between the content and context of the online and face-to-face courses that the instructor is teaching.

In sum, this study suggests that the experiences that faculty members acquire when teaching online can produce a change in the instructors' perceptions and understanding of online learning. Their new understanding, in turn, may result in changes to their face-to-face teaching practices. The findings show that, contrary to previous research speculations, technological skills and familiarity with distance education theories are not enough to assure the transfer of online pedagogical practices to face-to-face teaching. The findings also suggest that the instructors' process of changing the instructional design of a face-to-face course to the online environment triggers a reflection of their own practices, or what the theory of transfer calls forward-reaching transfer [25]. This reflection of practice also boosts awareness of potential pedagogical uses and encourages instructors to make changes in their face-to-face practice. Results from this study have the potential to inform innovations in faculty training and development and to encourage further research in this growing area. 


\section{REFERENCES}

1. Boettcher, J. \& R. Conrad. Faculty guide for moving teaching and learning to the web. Mission Viejo, CA: League for Innovation in the Community College, 1999.

2. Kosak, L., D. Manning, E. Dobson, L. Rogerson, S. Cotnam, S. Colaric, et al. Prepared to teach online? Perspectives of faculty in the University of North Carolina system. Online Journal of Distance Learning Administration VII(III): 2004.

3. Spector, J., \& I. de la Teja. Competencies for Online Teaching. Syracuse, NY, 2001.

4. Berge, Z. L. Facilitating computer conferencing: Recommendations from the field. Educational Technology 35(1): 22-30, 1995.

5. Cho, K. \& Z. L. Berge. Overcoming barriers to distance training and education [Electronic Version]. USDLA Journal, 16, 2002. Retrieved December 9, 2004 from http://www.usdla.org /html/journal/JAN02_Issue/article01.html.

6. Fetzner, M. Institutional support for online faculty: Expanding the model. In J. Bourne and J. C. Moore (Eds.), Elements of quality in online education: Practice and direction, Vol. 4, pp. 229-243. Needham, MA: Sloan-C, 2003.

7. McDonald, J. Is "as good as face-to-face" as good as it gets? Journal of Asynchronous Learning Networks 6(2): 10-23, 2002.

8. McKenzie, B. K., N. Mims, E. Bennett, \& M. Waugh. Needs, concerns and practices of online instructors. Online Journal of Distance Learning Administration 3(3): 2000.

9. O'Quinn, L. \& M. Corry. Factors that deter faculty from participating in distance education. Online Journal of Distance Learning Administration 5(4): 2002.

10. Jeris, L. \& A. Poppie. Screen to screen: A study of designer/instructor belief and actions leading to student outcomes in internet-based courses. Paper presented at the 43rd Adult Education Research Conference (AERC), Raleigh, NC, 2002.

11. Smith, G. G., D. Ferguson \& M. Caris. Teaching over the Web versus in the classroom: differences in the instructor experience. International Journal of Instructional Media 29(1): 61-67, 2002.

12. Suter, M. College faculty's transition to online teaching: from classroom space to virtual space. Unpublished doctoral dissertation. Capella University, 2001.

13. Guidera, S. College teaching in the virtual classroom: Faculty perceptions of the effectiveness of online instruction. Unpublished doctoral dissertation. Bowling Green State University, 2000.

14. Muilenburg, L. Y. \& Z. L. Berge. Barriers to distance education: A factor-analytic study. The American Journal of Distance Education 15(2): 7-24, 2001.

15. Stake, R. E. The art of case study research. Thousand Oaks, CA: Sage Publications, 1995.

16. Cree, V. E. \& C. Macaulay. (Eds.). Transfer of learning in professional and vocational education. London: Routledge, 2000.

17. Schunk, D. Learning theories: An educational perspective (4th Ed.). Upper Saddle River, NJ: Pearson Education, Inc, 2004.

18. Merriam, S. B. Qualitative research and case study application in education. San Francisco, CA: Jossey-Bass Publishers, 1998.

19. Miles, M. B. \& A. M. Huberman. Qualitative data analysis : an expanded sourcebook (2nd Ed.). Thousand Oaks, Calif.: Sage, 1994.

20. Stake, R. E. Case studies. In N. K. Denzin \& Y. S. Lincoln (Eds.), Handbook of Qualitative Research, 2nd ed., 435-454. Thousand Oaks, CA: Sage Publications, 2000

21. Schoenfeld-Tacher, R. \& K. A. Persichitte. Differential skills and competencies required of faculty teaching distance education courses. International Journal of Educational Technology 2(1), 2000.

22. Alessi, S. M. \& S. R. Trollip, S. R. Computer-based instruction: Methods and development. Englewood Cliffs, NJ: Prentice-Hall, 1985.

23. Lincoln, Y. \& E. Guba. Naturalistic inquiry. New York: Sage, 1985

24. Yin, R. K. Case study research design and methods (3rd Ed.). Thousand Oaks, CA: Sage Publications, 2003 
25. Salomon, G. \& D. N. Perkins. Rocky roads to transfer: Rethinking mechanisms of neglected phenomenon. Educational Psychologist 24(2): 113-142, 1989.

\section{ABOUT THE AUTHORS}

Dr. Norma I. Scagnoli,Ph.D. works as eLearning Specialist at the University of Illinois at UrbanaChampaign. Dr. Scagnoli has a PhD with emphasis in instructional technologies, and she has extensive experience in eLearning as instructor, administrator, and designer. Her research focuses on faculty development, instructional design and development and organization of elearning programs

Dr. Lydia P. Buki, Ph.D. is an Associate Professor in the College of Applied Health Sciences at the University of Illinois at Urbana-Champaign. Dr. Buki's research and professional interests are centered on health issues faced by Latina women in the United States.

Dr. Scott D. Johnson is CIO / Associate Dean for Online Learning in the College of Education at the University of Illinois at Urbana-Champaign. Dr. Johnson is also professor in the department of Human Resource Education. Dr. Johnson specializes in instructional design, instructional methods, and online learning. 